\title{
Terrestrial gamma radiation in Phuket Island, Thailand
}

\author{
Supitcha Chanyotha ${ }^{1}$, Chutima Kranrod $^{1 *}$, Shinji Tokonami $^{2}$, Napakan Suwankot ${ }^{1}$, \\ Karnwalee Pangza ${ }^{1}$, and Chanis Pornnumpa ${ }^{1}$
}

1Department of Nuclear Engineering, Faculty of Engineering, Chulalongkorn University, Bangkok 10330, Thailand

2Department of Radiation Physics, Institute of Radiation Emergency Medicine, Hirosaki University, Aomori 036-8564, Japan

E-mail: kranrodc@gmail.com*

\begin{abstract}
The aim of this study was to evaluate the level of terrestrial radioactivity on Phuket Island, which used to be the richest tin province in Thailand. We measured 124 survey points of terrestrial gamma dose rate at one meter above the surface of local soil along roads in the surroundings of Phuket Island. Another 31 survey points were examined inside an old ore-dressing plant. The terrestrial gamma dose rate of the Island (excluding the abandoned area of the old dressing plant) ranges from 20 to $900 \mathrm{nGy} \mathrm{h}^{-1}$ while the geometric mean Island value was $190 \mathrm{nGy} \mathrm{h}^{-1}$. Soil samples were also collected from specific areas indicating high gamma dose rates to analyze for activity concentrations of ${ }^{226} \mathrm{Ra},{ }^{232} \mathrm{Th}$ and ${ }^{40} \mathrm{~K}$. Based on these soil activities, the calculated terrestrial gamma dose rate indicating range between 25 and $520 \mathrm{nGy} \mathrm{h}^{-1}$. The corresponding annual effective doses ranged between 0.03 and $0.6 \mathrm{mSv} \mathrm{y}^{-1}$. The results of the terrestrial gamma dose rate obtained from direct measurement in the old tin dressing plant ranged from $110-17170 \mathrm{nGy} \mathrm{h}^{-1}$ with a mean value of $1410 \mathrm{nGy} \mathrm{h}^{-1}$. The terrestrial gamma dose rate calculated from soil samples in the dressing plant ranged from 590 to $206080 \mathrm{nGy} \mathrm{h}^{-1}$ which corresponded to annual effective dose of $0.7-250$ $\mathrm{mSv}^{-1}$. The dose rate in the almost whole area of Phuket Island is equivalent to the typical background level whereas the dose rate in the old tin dressing plant was 16 times higher than the background level.
\end{abstract}

Keywords: Terrestrial gamma dose rate, NORM, effective dose, tin, ${ }^{226} \mathrm{Ra},{ }^{232} \mathrm{Th},{ }^{40} \mathrm{~K}$.

ENGINEERING JOURNAL Volume 15 Issue 4

Received 13 July 2011

Accepted 31 August 2011

Published 1 October 2011

Online at http://www.ej.eng.chula.ac.th/eng/

DOI:10.4186/ej.2011.15.4.65 


\section{Introduction}

In this paper, Naturally Occurring Radioactive Material (NORM) is defined as: Materials which may contain elevated concentration of any of the primordial radionuclides or radioactive elements as they occur in nature, such as radium, uranium, thorium, potassium, and their radioactive decay products, that are undisturbed as a result of human activities [1]. Radiation levels presented by NORM are generally referred to as a component of the "natural background radiation." Elevated concentrations of these radionuclides are often found in certain geological materials, especially certain igneous rocks and ores [2]. Human activities that exploit these resources may lead to significantly enhanced concentrations of radionuclides (often referred to as technologically enhanced naturally occurring radioactive material or TENORM). In addition, some activities could result in the enhanced potential for exposure to naturally occurring radioactive materials in products, by-products, residues and wastes. The industries that generate NORM may release significant amounts of radioactive material into the environment resulting in the potential for widespread exposure to ionizing radiation. In the past, NORM-contaminated wastes and equipment were managed without any radiation control guidelines. A review of available data over the past decade shows that the occurrence of TENORM (and its associated health risks) may be significant enough to initiate more stringent guidelines. For example, there have been a growing number of national and international conferences and symposia that have focused on NORM/TENORM and numerous publications addressing NORM/TENORM have been prepared by regulators and several organizations [3-14]. NORM regulations have now been adopted or are in the process of being adopted in many countries including Thailand.

As a result of this increased interest, in the year 2002, the NORM: Radionuclides Analysis Research Project (NORM Project) with government and private sector co-operation was initiated and conducted by the Department of Nuclear Technology (former name), Faculty of Engineering, Chulalongkorn University. The aim of the project was to systematically characterize the occurrence and distribution of natural radiation arising from NORM throughout Thai industries. The hope was that the characterization data would be useful for developing regulatory programs that provided adequate radiation protection to the environment and public without unnecessarily burdening the respective industries. In Thailand the following industries involve NORM activities: metal (tin and zircon), fuel (coal, oil and gas), minerals (phosphate), and waterworks treatment facility.

To achieve the purpose of national NORM regulatory programs and without burdening the respective industries, from the natural risk point of view [15], it is important to establish reference levels of natural environmental radiation or natural background radiation incorporated in the ground, air, water, and other environmental materials for the country. In 2008, Chulalongkorn University joined a project entitled "Construction of natural radiation exposure study network" under a Memorandum of Understanding (MOU) with The National Institute of Radiological Science, Japan, to adopt the Program of Promotion of International Joint Research under the Special Coordination Funds for Promoting Science and Technology operated by the Ministry of Education, Culture, Sports, Science and Technology of Japan. The aims of the project were to assess the dose for natural radiation exposures using state-of-the-art measurement techniques in four Asian countries (China, India, Korea and Thailand).

In an effort to assist in the developing of Thai's NORM regulation, various products, by-products and waste-produced samples from the mineral industries were selected as a guide to NORM activities. To achieve the MOU program, the natural environmental radiation or natural background radiation levels have been investigated throughout the country, concentrating on major rock types and soil that has the potential of high concentrations of 3 key radionuclides $\left({ }^{226} \mathrm{Ra},{ }^{232} \mathrm{Th}\right.$ and $\left.{ }^{40} \mathrm{~K}\right)$. Particular attention was also paid to industries that had a high potential for accumulation of NORM from human activities. This paper presents information obtained from the natural radiation investigation taken in the south of the country, particularly on Phuket Island where heavy minerals were dressed and refined for more than two centuries [16, 17]. Results from other parts of the country will be presented elsewhere (Chanyotha et. al., in press). Although a few local studies have been conducted to determine the radioactivity concentrations of the terrestrial radionuclides and to assess the outdoor absorbed gamma dose rate in the Phuket area [18-20], detailed data regarding outdoor absorbed gamma dose rate by direct or ground measurement and the corresponding annual effective dose as well as information on 
soil contaminated from NORM activities have not been available for this region as well as for the country.

\section{Study Area}

We reviewed the available literatures to selected study areas based on present and old NORM practices, geology and airborne radiometric survey of Thailand [15-27]. A preliminary review concluded that, airborne radiometric data showed that uranium, thorium and potassium have high concentration along the west side of the country from the north down to the south of Thailand. Since the southern part of Thailand contains one of most extensive tin belt of the world [21, 22], many provinces in southern part of Thailand certainly have the experiences of NORM activity e.g. tin mining, dressing and smelting. This is especially, the case on Phuket, one of the richest tin provinces in Thailand [27]. Figure 1 shows the geology of Phuket Island which is characterized by granites emplaced in the pebbly mudstone of the Lower Permian-Ordovician [22, 23]. Generally, granite rocks are somewhat radioactive and contain 5 to 20 times the concentration of uranium in comparison to other common rock types [28-31]. Nevertheless, Mesozoic granites of Peninsular Thailand contain large amounts of radioactive elements, uranium and thorium and are related to tin and tungsten mineralization [25]. Consequently, the activity of tin dressing and refining during the past years which spread over the Phuket areas may cause the enhancement of the environmental dose rate due to Naturally Occurring Radioactive Material (NORM). As a result of this geologic background and the tendency to have NORM accumulation [16,24], Phuket Island was chosen as one of the principle study areas to measure the terrestrial gamma dose rate as part of our larger-scale investigation.

\subsection{General Information of Phuket Island}

Topography: mostly mountainous with a mountain range on the west of the island from the north to the south $(440 \mathrm{~km})$. The highest elevation of the island is Mai Thao Sip Song (Twelve Canes), at $529 \mathrm{~m}$ above sea level.

Total Area: $543.0 \mathrm{~km}^{2}$ (209.7 sq mi). Area rank Ranked $75^{\text {th }}$.

Population (2007): Total 321,802 (Ranked 68 $\left.{ }^{\text {th }}\right)$; Density $592.63 / \mathrm{km}^{2}\left(1,534.9 / \mathrm{sq}\right.$ mi) (Ranked $\left.6^{\text {th }}\right)$.

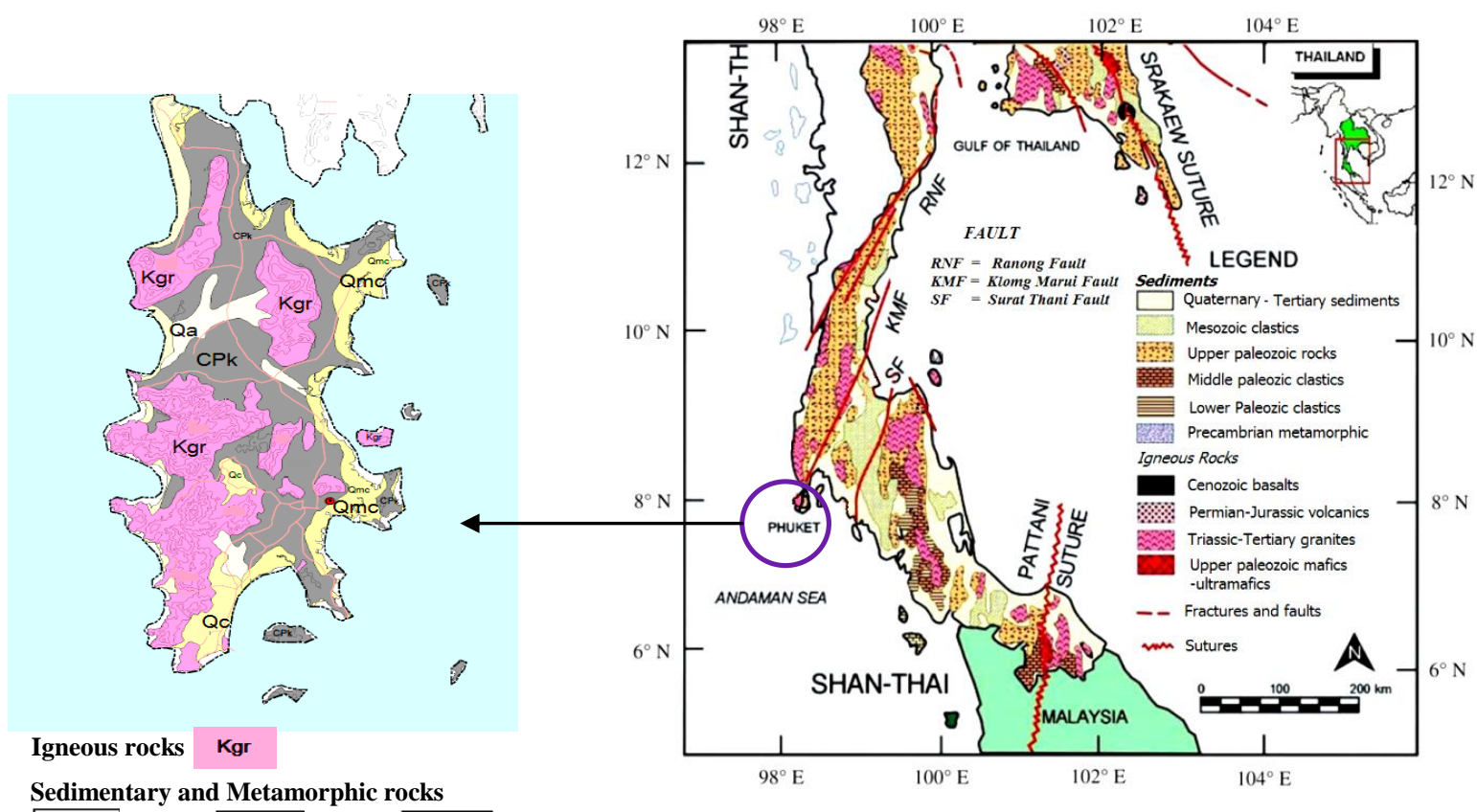

Qa Qme Qms Qc $\mathrm{CPk}$

$\mathrm{Kgr}=$ granite and granodiorite

$\mathrm{Qa}=$ Fluvial deposit, $\mathrm{Qc}=$ Colluvium, $\mathrm{Qmc}=$ Coastal deposit, $\mathrm{CPk}=$ mudstone and conglomerate

Fig. 1. Geology of Phuket Island. 


\section{Materials and Methods}

\subsection{Direct measurement system}

Gamma rays can penetrate appreciable thicknesses of air. This has implications for the "field of view" of airborne gamma ray spectrometers. A terrestrial point source, for example, can influence the measured detection rate at large lateral distances from the detector. Conversely, the measured gamma rate at an observation point, say $100 \mathrm{~m}$ above the ground, reflects the average concentration of the radioelements over a large area of many thousands of square meters [28]. Ground airborne measurements have several advantages over airborne radiometric measurement, mainly because it can provide detailed radioactivity measurements, especially on a small scale like Phuket Island. Therefore, portable and car-borne gamma ray spectrometry are normally used for both regional and detailed mapping surveys for estimating the surface concentrations of radioelements. For the field measurement, which is far away from our work place, we always brought 2 detectors, keeping one for a spare. In this study, 2 portable hand-held gamma-ray meters were used in the field studies (CANBERRA Model Inspector 1000, USA and Thermo Electron Corporation Model E-600, USA). Both detectors use 2" x 2" $\mathrm{NaI}$ crystals doped with thallium $[\mathrm{NaI}(\mathrm{Tl})]$. The instrument has an almost flat energy response to gamma radiations between $60 \mathrm{keV}$ and $2 \mathrm{MeV}$ [32]. This covers the majority of the significant gamma radiations emitted from terrestrial sources. Also, the detectors are reasonably sensitive to contributions from higher energy gamma radiation due to other environmental radionuclides including ${ }^{40} \mathrm{~K}$ and ${ }^{208} \mathrm{Tl}$. The interference from cosmic rays is negligible due to the detector's low response to high-energy cosmic gamma radiation. The instruments were calibrated for the higher count rates by the Thailand Institute of Nuclear Technology (TINT) as an IAEA recognized secondary standard calibration laboratory.

The measurements were performed by placing the detector about $1 \mathrm{~m}$ above the ground surface of local soil and allowing about 1 minute of measurement time in order to obtain a steady reading [28]. The measurement results are given as terrestrial gamma dose rate $\left(\mathrm{nGy} \mathrm{h}^{-1}\right)$. We note that although the INSPECTOR 1000 can obtain a pulse height distribution, it was used for dose rate readings only in this study. At any susppicious point we collected soil samples and analyzed for ${ }^{226} \mathrm{Ra},{ }^{232} \mathrm{Th}$ and ${ }^{40} \mathrm{~K}$ activity concentrations in our laboratory by using a carefully calibrated HPGe detector (see section 3.3).

To access the study areas quickly and easily, a car was used as our vehicle. A total of 124 measurements of the terrestrial gamma-ray dose mainly along roads in the surroundings of Phuket Island were collected. The measurement points were about 50-300 meters off of the road. In some urban or city areas, some measurement points were carried out at 1 meter above the pavement of the road. Another 31 survey points were taken in an abandoned area of a former tin ore-dressing plant by walkover survey technique through the plant. This old tin ore dressing house area had been abandoned for more than 15 years. The geographical location of each survey point was marked by means of a Global Positioning System (GPS) and recorded (black circle symbols) as shown on left side of Fig. 2.

\subsection{Sampling and sample preparation}

A total of 17 soil samples from areas that had high dose rate readings (e.g., soil samples inside the abandoned dressing plant) and low dose rate readings nearby were collected and analyzed to identify the gamma-ray emitting radioisotopes. The geographical location of each sample collection point was marked by GPS and recorded (star and triangle symbol) as shown on the right side of Fig. 2. Each collected soil sample consisted of approximately $500 \mathrm{~g}$ of material and was collected from a depth of 5$10 \mathrm{~cm}$ by soil core logging $(7 \mathrm{~cm}$ diameter). All samples were packed in plastic non-radioactive material, sealed and carefully labelled to avoid misidentification and contamination. All samples were oven dried at $100{ }^{\circ} \mathrm{C}$ to a constant weight, pulverized using a centrifugal ball mill and homogenized using a $500 \mu \mathrm{m}$ mesh size sieve. Then samples were placed in cylindrical gas-tight plastic containers that had the same geometry as the containers used for efficiency calibration. The samples were kept for at least one month to allow radioactive equilibrium between ${ }^{226} \mathrm{Ra}$ and ${ }^{222} \mathrm{Rn}$ before all measurements [33]. These soil samples were analyzed for 3 principal NORM isotopes: radium-226 $\left({ }^{226} \mathrm{Ra}\right)$, thorium$232\left({ }^{232} \mathrm{Th}\right)$ and potassium $-40\left({ }^{40} \mathrm{~K}\right)$. These radioisotopes are also normally used to calculate the terrestrial gamma dose rate $\left(\mathrm{nGy} \mathrm{h}^{-1}\right)$ to the public. 


\subsection{Calibration of equipment/energy calibration}

A low-background gamma-ray spectroscopy system, based on a passively shielded co-axial hyperpure germanium (HPGe) detector with $25 \%$ relative efficiency coupled to an integrated signal processor and multichannel analyzer together with an interface to a PC, was used for radionuclide identification and activity measurements of the soil samples. A uniform distribution of radionuclides within each individual sample was assumed for the purpose of this study. In addition, all the decay products including gaseous ${ }^{222} \mathrm{Rn}$ and ${ }^{220} \mathrm{Rn}$ from the ${ }^{238} \mathrm{U}$ and ${ }^{232} \mathrm{Th}$ series respectively were considered to be in equilibrium with their parents and as such, the effects of emanation of the gaseous components were not taken into account. Energy and efficiency calibrations of the detector were carried out using three different IAEA standard reference materials: IAEA-RGU-1, IAEA-RGTh-1, and IAEA-RGK-1 [34]. The efficiency corrected intensities of the measured discrete gamma ray lines at energies 911.2, 968.9 $\left({ }^{228} \mathrm{Ac}\right), 583.2,860.5$ and $2614.5 \mathrm{keV}\left({ }^{208} \mathrm{Tl}\right)$ were used to determine the activity concentrations of ${ }^{228} \mathrm{Ra}$ (from ${ }^{232} \mathrm{Th}$ decay chain); the gamma ray lines at $351.9\left({ }^{214} \mathrm{~Pb}\right), 609.3,1120.3,1238.1$ and $1764.5 \mathrm{keV}$ $\left({ }^{214} \mathrm{Bi}\right)$ were used to determine the activity concentrations of ${ }^{226} \mathrm{Ra}$ (from the ${ }^{238} \mathrm{U}$ decay chain). The $1460 \mathrm{keV}$ gamma ray line was used to determine the activity concentration of ${ }^{40} \mathrm{~K}$.

The activity of each radionuclide was calculated according to IAEA recomendations [35] and was given by:

where $A=$ sample activity concentration in Bq. $\mathrm{kg}^{-1}$

$$
A=\frac{N_{L}}{\varepsilon \cdot P_{\gamma} \cdot m \cdot t}
$$

$N_{L}=$ net counts measured under the photo peak

$\varepsilon=$ system detection efficiency

$P \gamma=$ absolute transition probability by gamma decay for the selected energy

$m=$ sample mass in kilograms

$t=$ counting time in seconds.

The lower limit of detection (LLD) was given by Eq. (2), for 95\% confidence level [35]:

$$
L L D=\frac{N_{L \min }}{\varepsilon \cdot P_{\gamma} \cdot m \cdot t}
$$

where $\mathrm{N}_{\mathrm{Lmin}}$ was the minimum net area of the measured spectrum:

$$
N_{L \min }=4.66 \sqrt{F_{c}}
$$

and $F_{c}$ was the Compton background in the region of the selected gamma line in the sample spectrum.

\subsection{Dose calculation}

In order to assess any radiological hazard, the absorbed dose rate $\left(\mathrm{nGy} \mathrm{h}^{-1}\right)$ in air at $1 \mathrm{~m}^{-1}$ above the ground surface due to the mean specific activities of ${ }^{226} \mathrm{Ra},{ }^{232} \mathrm{Th}$ and ${ }^{40} \mathrm{~K}\left(\mathrm{Bqkg}^{-1}\right)$ in the soil samples, are calculated using the following formula reported by UNSCEAR 2000 [11].

$$
\mathrm{D}\left(\mathrm{nGy} \mathrm{h}^{-1}\right)=0.462 \mathrm{~A}_{\mathrm{Ra}}+0.604 \mathrm{~A}_{\mathrm{Th}}+0.0417 \mathrm{~A}_{\mathrm{K}}
$$

where $\mathrm{D}$ is the absorbed dose rate in $\mathrm{nGy} \mathrm{h}^{-1}$, and $\mathrm{A}_{\mathrm{Ra}}, \mathrm{A}_{\mathrm{Th}}$ and $\mathrm{A}_{\mathrm{K}}$ are the specific activities in $\mathrm{Bg} \mathrm{kg}^{-1}$ of ${ }^{226} \mathrm{Ra},{ }^{232} \mathrm{Th}$, and ${ }^{40} \mathrm{~K}$ respectively. The dose coefficients in unit of $n \mathrm{~Gy} \mathrm{~h} \mathrm{~h}^{-1}$ per $\mathrm{Bq} \mathrm{kg}^{-1}$ were taken from Saito and Jacob [38].

The annual effective dose rate from outdoor gamma radiation was estimated by taking into account the conversion coefficient from the absorbed dose in air to the effective dose $\left(0.7 \mathrm{~Sv} \mathrm{~Gy}^{-1}\right)$ and an outdoor occupancy factor of 0.2 received by adults. Under these assumptions, the annual effective dose equivalent was calculated by the following equation [11]:

$$
\mathrm{E}\left(\mathrm{mSv}^{-1}\right)=\mathrm{D}\left(\mathrm{nGyh}^{-1}\right) \times 8760(\mathrm{~h}) \times 0.2 \times 0.7\left(\mathrm{~Sv} \mathrm{~Gy}^{-1}\right) \times 10^{-6}
$$




\section{Results and Discussion}

\subsection{The outdoor gamma dose rate from direct measurements}

The terrestrial gamma dose rate measurements were done during February 2010. A total of 124 data points were collected along the selected route, with the distance between each survey point at about 2 $\mathrm{km}$ apart, covering approximately a total distance of $285 \mathrm{~km}$. Figure 2 (left) shows the survey point mapped with the geology of Phuket Island. The terrestrial gamma dose rate of the island (excluding the abandoned area of the old dressing plant) obtained at 1 meter above ground ranged from 20 to $900 \mathrm{nGy}$ $\mathrm{h}^{-1}$, with the geometric mean value of $185 \mathrm{nGy} \mathrm{h}^{-1}$. The distribution of terrestrial gamma dose rate data is presented as a histogram in Fig. 3. This shows that the data follow a log-normal distribution. The absorbed dose rate at the famous, Patong beach, ranged between 52 and $80 \mathrm{nGy} \mathrm{h}^{-1}$ which agreed with the result of $47 \mathrm{nGy} \mathrm{h}^{-1}$ reported earlier by D. Malaian, et al. [36]. The highest dose rate of $900 \mathrm{nGy} \mathrm{h}^{-1}$ was found on the surface mountain soil located on the south coast of the island. At that time of this investigation, mountain soil was being evacuated for constructing of a local road nearby. In the city area, we found a relatively high absorbed dose rate of $492 \mathrm{nGy} \mathrm{h}^{-1}$ on the pavement of one main road near a population center which is higher than the nearby uncovered soil about 2-3 times. We cannot be sure of the explanation for this anomaly but suspect that some of the aggregate used in making the concrete for the road surface here contained some NORM material.

The corresponding outdoor effective doses were calculated from direct measurement at various locations (excluding the data of dressing plant) varied between 0.02 and $1.10 \mathrm{mSv} \mathrm{y}^{-1}$ with an average value of $0.23 \mathrm{mSv} \mathrm{y}^{-1}$.

The results of the terrestrial gamma dose rate obtained inside the abandoned area of the old dressing plant in the southeastern part of the island show dose rates ranged from 110-17,200 $\mathrm{nGy} \mathrm{h}^{-1}$ with a mean value of $1410 \mathrm{nGy} \mathrm{h}^{-1}$. The corresponding annual outdoor effective dose value is $1.73 \mathrm{mSv} \mathrm{y}^{-1}$. It was found that soils inside the plant area have ${ }^{232} \mathrm{Th}$ concentrations greater than near-by soil by about 100 times. This indicated indicates that the area does did become contaminated occur during certain mineral dressing processes.

Measured data of terrestrial gamma dose rates were mapped to simulate the whole Phuket region, as shown in Fig. 2 (right) using ArcGIS software which by applying an inverse distance-weighted (IDW) method, which weights the points closer to the prediction location greater than those farther away. It can be seen from Fig. 2 (right) that the higher gamma dose rates are found in the western part of the region which consists of igneous rocks. The overall pattern of our contour map specifies the areas of the high intensity of gamma dose rate and some results matched the airborne radiometric results of DMR and other works $[17,37]$. To clarify our measurement results are related to the geology of the island; with high areas mainly characterized by granite rock. Our results compare to the results of Jehanno et. al. [11] who reported in the UNSCEAR 2000 document, that the central region of France, which is characterized by granites, and similar rocks has an absorbed dose in air ranged from 20-400 $\mathrm{nGy} \mathrm{h}^{-1}$. This central region of France was reported as "areas of high natural radiation background" [11].

\section{2. ${ }^{226} \mathrm{Ra},{ }^{232} \mathrm{Th}$ and ${ }^{40} \mathrm{~K}$ activity concentrations in the soil samples}

The analysis of the 12 soil samples collected from sites of high gamma readings and nearby (excluding the old dressing plant) revealed that the activity concentrations of ${ }^{226} \mathrm{Ra},{ }^{232} \mathrm{Th}$ and ${ }^{40} \mathrm{~K}$ in the soil samples varied between 20 to 380,25 to 530 , and 36 to $2610 \mathrm{~Bq} \mathrm{~kg}^{-1}$, respectively. It should be noted that, all collected soil samples in this study are not representative of the soil of Phuket areas because the sampled soils were selected from areas where gamma dose rate reading were high. We found that all soil samples have activity concentrations of ${ }^{232} \mathrm{Th}$ much greater than ${ }^{226} \mathrm{Ra}$. The high activity concentrations of 3 isotopes were found in the soil sample collected from the mountain (ID: PK 77-78, 81 ) which contains abundant granitic rocks (see Fig. 2). However, activity concentrations of ${ }^{226} \mathrm{Ra},{ }^{232} \mathrm{Th}$ and ${ }^{40} \mathrm{~K}$ values obtained from the selected areas agreed with the results presented by Plaisonpon, et al. [17] and Boonkrongcheep, et al. [37] except those found in the soil of East Asian countries as shown in Table 2 which all have values less than ours. Mean concentrations for ${ }^{226} \mathrm{Ra},{ }^{232} \mathrm{Th}$, and ${ }^{40} \mathrm{~K}$ in soil worldwide reported by UNSCEAR 2000 is as 35, 30, and 400, respectively. 
The activity concentrations of all 3 isotopes in 5 soil samples collected from inside the old dressing plant (ID TS 33-36), were all higher than the near-by soils (soil ID PK 127-132) by as much as tenfold as shown in Table 1. This is a good example of TENORM.

We have made a comparison between our results and the results of Mohsen, et. al. [39] who reported about the activity concentration of 3 key NORM in the sediments collected from among processing ponds, Malaysia, as shown in Table 2 . The activity concentrations of 3 NORM isotopes in the dressing plant's soil were greater than the among sediments.
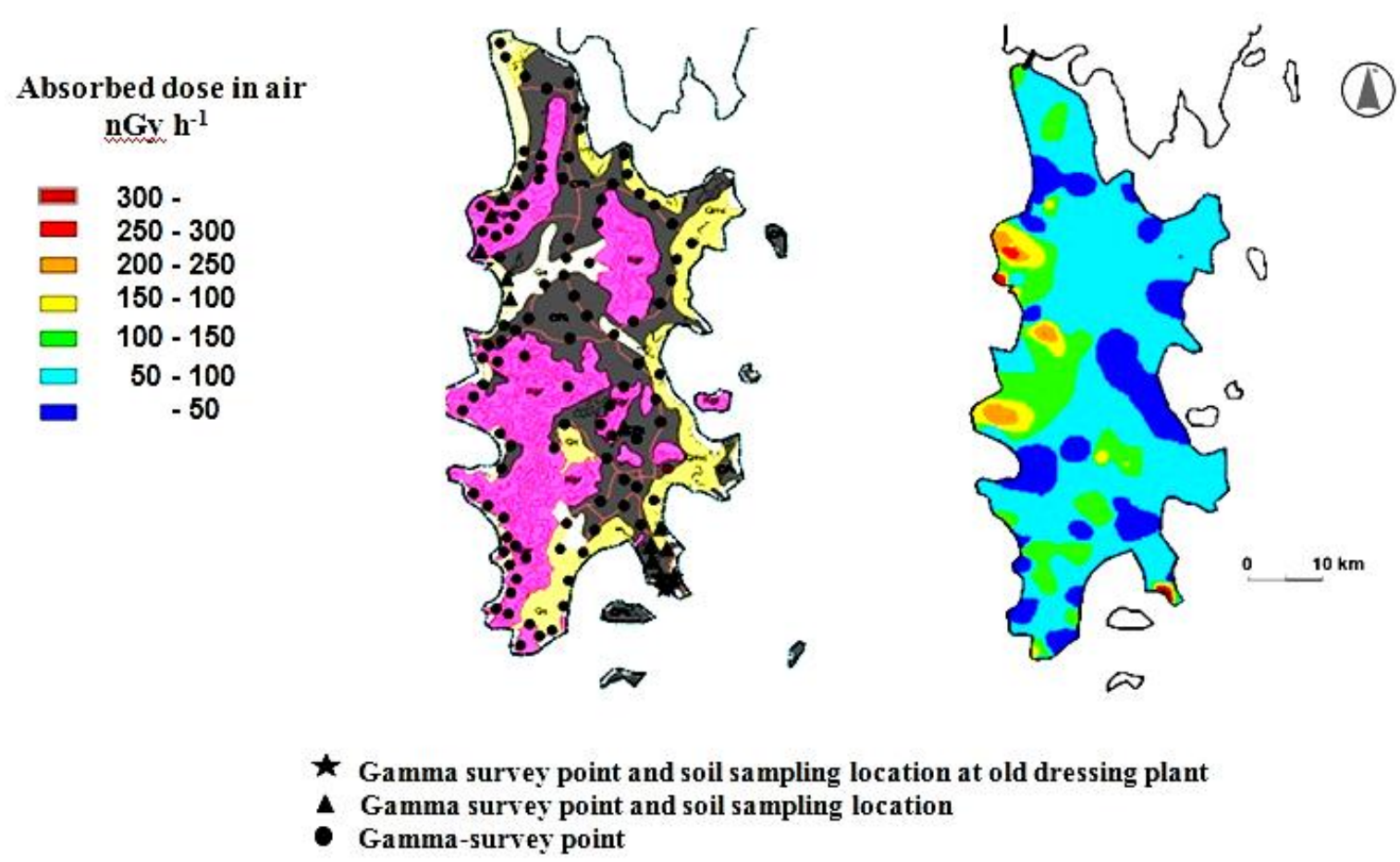

Fig. 2. Geological map, terrestrial gamma dose rate survey and sampling points (left), Contour map (right).

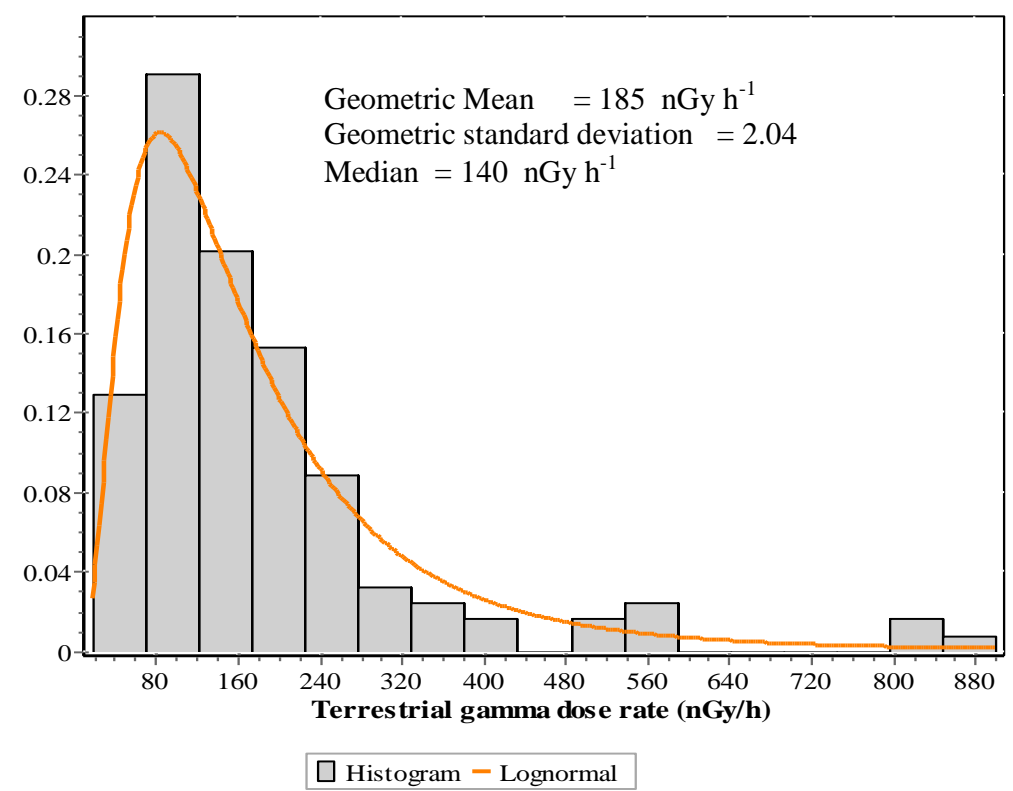

Fig. 3. Frequency histogram and Log-normal distribution of terrestrial gamma dose rate survey. 
Table 1. The radioactivity concentrations of ${ }^{226} \mathrm{Ra},{ }^{232} \mathrm{Th}$ and ${ }^{40} \mathrm{~K}$, terrestrial gamma dose rate (both calculated and direct measurement) and the corresponding annual effective dose for Phuket soil samples.

\begin{tabular}{|c|c|c|c|c|c|c|c|c|}
\hline \multirow{2}{*}{$\begin{array}{l}\text { Sample } \\
\text { ID }\end{array}$} & \multirow{2}{*}{$\begin{array}{c}\text { Geology* } \\
\text { or sampling location }\end{array}$} & \multicolumn{3}{|c|}{$\begin{array}{l}\text { Activity concentration } \\
\left(\mathrm{Bq} \mathrm{kg}^{-1}\right)\end{array}$} & \multicolumn{2}{|c|}{$\begin{array}{l}\text { Terrestrial gamma dose } \\
\quad \text { rate }\left(n G y h^{-1}\right)\end{array}$} & \multirow{2}{*}{$\begin{array}{c}\text { Ratio } \\
\text { Soil/ } \\
\text { measurement }\end{array}$} & \multirow{2}{*}{$\begin{array}{c}\begin{array}{c}\text { Annual } \\
\text { effective }\end{array} \\
\text { dose }^{\mathbf{b}} \\
\left(\mathbf{m S v} \mathbf{y}^{-1}\right)\end{array}$} \\
\hline & & ${ }^{226} \mathrm{Ra}$ & ${ }^{232}$ Th & ${ }^{40} \mathbf{K}$ & $\begin{array}{c}\text { soil } \\
\text { concentration }\end{array}$ & $\begin{array}{c}\text { direct } \\
\text { measurement }\end{array}$ & & \\
\hline PKT70 & $\begin{array}{l}\text { Sediment }(\mathrm{Qmc}) / \\
\text { Temple }\end{array}$ & $50 \pm 1$ & $160 \pm 2$ & $70 \pm 4$ & 120 & 150 & 0.8 & 0.2 \\
\hline PKT75 & Sediment (Qmc) & $100 \pm 1$ & $530 \pm 5$ & $180 \pm 10$ & 370 & 370 & 1.0 & 0.5 \\
\hline PKT77 & $\begin{array}{l}\text { Granite }(\mathrm{Kgr}) / \\
\text { mountain }\end{array}$ & $190 \pm 2$ & $270 \pm 4$ & $2610 \pm 50$ & 360 & 590 & 0.6 & 0.4 \\
\hline PKT78 & $\begin{array}{l}\text { Granite (Kgr)/ } \\
\text { mountain }\end{array}$ & $380 \pm 2$ & $450 \pm 4$ & $1820 \pm 30$ & 520 & 900 & 0.6 & 0.6 \\
\hline PKT81 & $\begin{array}{l}\text { Granite }(\mathrm{Kgr}) / \\
\text { mountain }\end{array}$ & $140 \pm 1$ & $320 \pm 3$ & $1390 \pm 20$ & 320 & 210 & 1.5 & 0.4 \\
\hline PKT83 & Sediment (Qa) & $50 \pm 1$ & $150 \pm 2$ & $70 \pm 10$ & 150 & 420 & 0.3 & 0.2 \\
\hline PKT85 & $\begin{array}{l}\text { Sediment } \\
\text { (Qa)/Lagoona Hotel }\end{array}$ & $20 \pm 1$ & $30 \pm 1$ & $80 \pm 4$ & 30 & 320 & 0.1 & 0.03 \\
\hline PKT128 & Sediment (Cpk) & $50 \pm 1$ & $70 \pm 2$ & $210 \pm 10$ & 70 & & & 0.1 \\
\hline PKT129 & $\begin{array}{l}\text { Sediment }(\mathrm{Cpk}) / \text { Near } \\
\text { Phuket port }\end{array}$ & $90 \pm 1$ & $130 \pm 3$ & $480 \pm 10$ & 140 & & & 0.2 \\
\hline PKT130 & Sediment (Cpk) & $10 \pm 1$ & $30 \pm 1$ & $40 \pm 3$ & 30 & NA & NA & 0.03 \\
\hline PKT131 & $\begin{array}{l}\text { Sediment }(\mathrm{Cpk}) / \\
\text { Radison Hotel }\end{array}$ & $30 \pm 1$ & $50 \pm 2$ & $230 \pm 10$ & 50 & & & 0.1 \\
\hline PKT132 & $\begin{array}{l}\text { Sediment }(\mathrm{Cpk}) / \mathrm{On} \\
\text { Makham bay }\end{array}$ & $40 \pm 1$ & $100 \pm 3$ & $860 \pm 20$ & 110 & & & 0.1 \\
\hline TS33 & $\begin{array}{l}\text { Inside Old dressing } \\
\text { plant }\end{array}$ & $560 \pm 3$ & $500 \pm 10$ & $260 \pm 20$ & 590 & 1,020 & 0.6 & 0.7 \\
\hline TS34 & $\begin{array}{l}\text { Inside Old dressing } \\
\text { plant }\end{array}$ & $1,300 \pm 10$ & $2,300 \pm 20$ & $210 \pm 10$ & 2,000 & 4,030 & 0.5 & 2.5 \\
\hline TS35 & $\begin{array}{l}\text { Inside Old dressing } \\
\text { plant }\end{array}$ & $1,990 \pm 10$ & $3,170 \pm 20$ & $540 \pm 16$ & 2,850 & 2,100 & 1.2 & 3.5 \\
\hline TS36 & $\begin{array}{l}\text { Inside Old dressing } \\
\text { plant }\end{array}$ & $3,790 \pm 20$ & $10,500 \pm 150$ & $1,770 \pm 46$ & 8,140 & 8,230 & 1 & 10.0 \\
\hline TS41 & $\begin{array}{l}\text { Inside Old dressing } \\
\text { plant }\end{array}$ & $14,300 \pm 30$ & $329,900 \pm 2,400$ & $5,400 \pm 92$ & 206,000 & 17,200 & 12 & 250 \\
\hline
\end{tabular}

${ }^{\mathrm{a}}$ The errors quoted represent statistical uncertainties in the measurements.

${ }^{\mathrm{b}}$ Annual effective dose were calculated by the activity concentrations of ${ }^{226} \mathrm{Ra},{ }^{232} \mathrm{Th}$ and ${ }^{40} \mathrm{~K}$ in the soil samples.

$\mathrm{NA}=$ Data not available.

* Estimate from geological map (Fig. 1). 
Table 2. Comparison of our results for mean radioactivity concentrations of ${ }^{226} \mathrm{Ra},{ }^{232} \mathrm{Th}$ and ${ }^{40} \mathrm{~K}$, terrestrial gamma dose rate calculated from soil samples and the corresponding annual effective dose for Phuket soil sample with East Asia countries.

\begin{tabular}{|c|c|c|c|c|c|c|}
\hline \multirow{2}{*}{ Location } & \multirow{2}{*}{ Type of sampling } & \multicolumn{3}{|c|}{$\begin{array}{l}\text { Mean activity concentration }{ }^{\mathrm{a}} \text { (range) } \\
\qquad\left(\mathrm{Bq} \mathrm{kg}^{-1}\right)\end{array}$} & \multirow{2}{*}{ 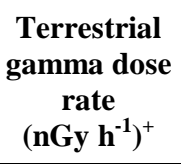 } & \multirow{2}{*}{$\begin{array}{c}\text { Annual effective } \\
\text { dose }^{++} \\
\left(\mathbf{m S v} \mathbf{y}^{-1}\right)\end{array}$} \\
\hline & & ${ }^{226} \mathrm{Ra}$ & ${ }^{232}$ Th & ${ }^{40} \mathbf{K}$ & & \\
\hline \multirow{2}{*}{ This study } & Soil & $94(20-390)$ & $190(25-530)$ & $720(36-2610)$ & 190 & 0.23 \\
\hline & $\begin{array}{l}\text { Soil inside old } \\
\text { dressing plant }\end{array}$ & $\begin{array}{c}4,400 \\
(600-14300)\end{array}$ & $\begin{array}{c}69,300 \\
(500-330000)\end{array}$ & $\begin{array}{c}1640 \\
(210-5400)\end{array}$ & 43930 & 57 \\
\hline $\begin{array}{l}\text { P.Plaisonpon et al. } \\
\text { [17] }\end{array}$ & Soil & $133(16-272)^{*}$ & $82(0-340)$ & $435(0-1455)$ & 130 & 0.16 \\
\hline $\begin{array}{l}\text { R. Boonkrongcheep } \\
\text { et. al. [20] }\end{array}$ & Soil & $213(0-831)$ & $204(20-1014)$ & $4092(202-18800)$ & 390 & 0.48 \\
\hline $\begin{array}{l}\text { N. Mohsen et. al. } \\
{[39]}\end{array}$ & $\begin{array}{c}\text { Sediment in amang } \\
\text { processing pond, } \\
\text { Malaysia } \\
\end{array}$ & $41-190$ & $105-516$ & $75-848$ & $85-440$ & $0.10-0.53$ \\
\hline \multicolumn{7}{|l|}{ East Asia [11] } \\
\hline China & Soil & $32(2-440)$ & $41(1-360)$ & $440(9-1800)$ & 60 & 0.07 \\
\hline Hong Kong & Soil & $59(20-110)$ & $95(16-200)$ & $530(80-1100)$ & 110 & 0.13 \\
\hline India & Soil & $29(7-81)$ & $64(14-160)$ & $400(38-760)$ & 70 & 0.08 \\
\hline Japan & Soil & $33(6-98)$ & $28(2-88)$ & $310(15-990)$ & 45 & 0.06 \\
\hline Kazakstan & Soil & $35(12-120)$ & $60(10-220)$ & $300(100-1200)$ & 65 & 0.08 \\
\hline Malaysia & Soil & $67(38-94)$ & $82(63-110)$ & $310(170-430)$ & 100 & 0.11 \\
\hline Thailand & Soil & $48(11-78)$ & $51(7-120)$ & $230(7-712)$ & 60 & 0.08 \\
\hline World average & Soil & 35 & 30 & 400 & 51 & 0.07 \\
\hline
\end{tabular}

+ Average value, Calculated Effective Dose rate based on Eq. (4).

+ Average value Calculated Annual Effective Dose rate based on Eq. (5).

* Reported as ${ }^{238} \mathrm{U}$.

\subsection{Dose assessment from soil sample}

The terrestrial gamma dose rate in the outdoor air can be evaluated from the activity concentrations of the ${ }^{226} \mathrm{Ra},{ }^{232} \mathrm{Th}$ and ${ }^{40} \mathrm{~K}$ measured in soil samples. The results show that the terrestrial gamma dose rate (excluding the data from the dressing plant) ranged between 25 and $520 \mathrm{nGy} \mathrm{h}^{-1}$ which is significantly higher than the world mean range values between 20 and $90 \mathrm{nGy} \mathrm{h}^{-1}$ [11]. The average mean value of outdoor gamma dose rate from the soil samples is $190 \mathrm{nGy} \mathrm{h}^{-1}$ which is higher than the mean world mean values of $51 \mathrm{nGy} \mathrm{h}^{-1}$ as reported by UNSCEAR 2000, whereas lower than the mean of $390 \mathrm{nGy} \mathrm{h}^{-1}$ reported by Boonkrongcheep [20].

The corresponding outdoor effective doses at various locations (excluding the data of dressing plant) where the soil samples have been collected varied between 0.03 and $0.6 \mathrm{mSv} \mathrm{y}^{-1}$ with an average value of $0.23 \mathrm{mSv} \mathrm{y}^{-1}$. This average value is equal to the average value of direct terrestrial gamma survey. On the other hand, the average value is still lower than the maximum value reported by Boonkrongcheep [20] but greater than the world average annual outdoor effective dose value of 0.07 $\mathrm{mSv} \mathrm{y}^{-1}$ as reported by UNSCEAR 2000. However, as previously noted, all collected soil samples in this study are not representative of the soil of Phuket areas. 
The terrestrial gamma dose rate from soil inside the old dressing plant, ranged from 590 to 206,100 $n G y h^{-1}$. The annual outdoor effective dose value corresponding to these gamma dose rates ranges from 0.7 to $250 \mathrm{mSv} \mathrm{y}^{-1}$. Both these values are very high, but this area belongs to the local government and has been abandoned for more than 15 years. Indeed, these mineral residues should be carefully managed and controlled under proper regulation before releasing the land for other purposes since it might be a source of exposure to workers and the public. In addition, further assessment of indoor and outdoor radon/thoron exposure in these areas should be given a high priority.

\section{Conclusion}

We have investigated the terrestrial gamma dose rate on Phuket Island. The gamma dose rate contours were mapped to estimate the absorbed dose rate for the whole island. Elevated gamma dose rates readings have been obtained in several areas of Phuket, especially in the western sections. From this work, it is also found that several areas in the island have the annual outdoor effective dose higher than the world average of $0.07 \mathrm{mSv} \mathrm{y}^{-1}$ as specified by UNSCEAR 2000. A good "TENORM" example was observed during our study which indicated that the enrichment (enhancement) of radium and thorium isotopes does occur in waste residues during certain tin dressing processes. However, the dose rates on much of Phuket Island are within typical background values while the dose rates within the old tin dressing plant are elevated by as much as 16 times background. These terrestrial gamma dose rates and NORM data obtained from this study will be useful for preparing NORM regulations for Thailand.

\section{Acknowledgement}

The authors would like to express our thanks to the supporters: the Thai government, Chulalongkorn University, the Thai industries that participated in the NORM project. We also wish to thanks the Special Coordination Funds for Promoting Science and Technology of Ministry of Education, Culture, Sports, Science and Technology, Japan for the grant-in-aid support under the "Construction of Natural Radiation Exposure Study Network". We would like to thank Dr. Masahiro Hosoda, Graduate School of Health Sciences, Hirosaki University, Japan for his support to prepare the contour map in this study.

\section{References}

[1] United States Environmental Protection Agency, "Technologically Enhanced Naturally Occurring Radioactive Materials from Uranium Mining," EPA 402-R-05-007, Washington, DC, 2008.

[2] International Atomic Energy Agency, "Extent of Environmental Contamination by Naturally Occurring Radioactive Material (NORM) and Technological Options for Mitigation", Technical report series No.419, 2003.

[3] J. Tadmor, "Radioactivity from coal-fired power plants: a review". J. Environ. Radioact., vol. 4, pp. 177-204, 1986.

[4] C. M. Gramaccioli, T. V. Segalstad, "A uranium and thorium rich monazite from a south-alpine pegmatite at Piona, Italy,"American Mineralogist, vol. 63, pp. 757-761, 1978.

[5] A. Martin, S. Mead, and B. O. Wade, Materials containing natural radionuclides in enhanced concentrations, EUR 17625 EN, European Commission, Brussels, 1997.

[6] G. Lineley, "International developments on the concepts of exclusion, exemption and clearance," in Proc. of the 2nd International Symposium on the Treatment of Naturally Occurring Radioactive Materials, NORM II, Nov. 10-13, Krefeld, Germany, 1998.

[7] RCA, "RCA expert advisory group meeting to review and develop radiation protection guidance for naturally occurring radioactive materials in the oil and gas and other mineral extraction and processing industries," in Proc. of Australian Nuclear Science and Technology Organization, 1998 .

[8] J. S. S. Penfold, S. F. Mobbs, J.-P. Degrange, and T. Schneider, "Establishment of reference levels for regulatory control of workplaces where materials are processed which contain 
enhanced levels of naturally-occurring radionuclides," Radiation Protection 107, Luxembourg: Office for Official Publications of the European Communities, 1999.

[9] US National Academy of Sciences, Evaluation of Guidelines for Exposures to Technological Enhanced Naturally Occurring Radioactive Materials, National Academy Press, Washington D.C., 1999.

[10] Canadian NORM working group of the federal provincial territorial, Radiation protection committee, Canadian Guidelines for the Management of Naturally Occurring Radioactive Materials (NORM), 2000 .

[11] United Nations Scientific Committee on the Effects of Atomic Radiation, Sources and effects of ionizing radiation, Vol. 1, New York: United Nations, 2000.

[12] International Atomic Energy Agency, "Naturally Occurring Radioactive material (NORM IV)," in Proceedings of an International Conference held in Szcyrk, Poland, May 17-21, 2004.

[13] International Atomic Energy Agency, "Assessing the need for radiation protection measures in work involving minerals and raw materials," Safety Reports Series No. 49, Vienna: IAEA, 2006.

[14] A. K. Mohanty, D. Sengupta, S. K. Das, S. K. Saha, and K. V. Van, "Natural radioactivity and radiation exposure in high background area at Chhatrapur beach placer deposit of Orissa," India. J. Environ. Radioactivity, vol. 75, pp. 15-33, 2004 .

[15] S. Ishihara, T. Moriyama, H. Hirano, "REE-rich granites of Ko Samui, Ko Phuket and Yod Nam Mine in the Southern Thailand," in the International Symposia on Geoscience Resources and Environments of Asian Terranes (GREAT 2008), 4th IGCP 516, and 5th APSEG., Bangkok, Thailand, 2008, pp. 238-247.

[16] G. F. Brown, S. Buravas, C. Charaljavanaphet, N. Jalichandra, W. D. Johnston Jr., V. Srethaputra, and G. C. Tayor Jr., "Geological reconnaissance of the mineral deposits of Thailand,”. U.S. Geol. Survey Bull., vol. 984, pp. 1-183, 1951.

[17] P. Phutthapiban and C. M. Cray, "Age and tin-tungsten mineralization of Phuket granites, Thailand," in Conference on Geology and Mineral Resources of Thailand, Bangkok, Thailand, 1983, pp. 30-38.

[18] P. Plaisonpon, P. Visuthisamajam, and T. Bhongsuwan, "Estimation of Annual Effective dose from natural radioactive materials in Phuket Province," Journal of the Nuclear Society of Thailand, vol. 8, no. 1, pp. 27-39, 2008.

[19] P. Kessaratikoon and U. Youngchauy, "Measurement of specific activity of natural and antropogenic radionulides in beach sand samples of Phuket province after tsunami disaster using gamma-ray spectrometry," Journal of the Nuclear Society of Thailand, vol. 9, no.1, pp. 27-35, 2009.

[20] R. Boobkrongcheep and P. Kessaratikoon, "Quantitative and qualitative measurement of radioactivity in beach sand from Patong beach in Phuket Province" in the 33rd Congress on Science and Technology of Thailand, Walailak University, NaKhon Si Thammarat, Thailand, pp. 2007.

[21] Department of Mineral resources. (2011) Mineral resources of Thailand. Available http://www.dmr.go.th/ewtadmin/ewt/dmr_web/main.php?filename=Mineral_re_En

[22] P. Dheeradilok, T. Wongwanich, W. Tansathien, and P. Chaodumrong, "An Introduction to Geology of Thailand," in National Conference on Geologic Resources of Thailand: Potential for future Development, Bangkok, Thailand, 1992, pp. 737-752.

[23] S. Nakapadungrat, R. D. Beckinsale, and S. Suensilpong, "Geochronology and Geology of Thai Granites," in Proceedings of the Conference on Applications of Geology and the National Development, Bangkok, Thailand, 1984.

[24] United Nations Economic Commission for Asia and the Far East (Unesco), "Geological map of Asia and the Far East," in Explanatory note, 2nd ed, Paris, France: Imprimerie Louis-Lean, pp. $1-100,1971$.

[25] S. Ishihara, H. Sawata, K. Shibata, S. Terashima, S. Arrykul, and K. Sato, "Granites and Sn-W deposits of Peninsular Thailand," in Granitic Magnetism and Related Mineralization, S. Ishihara, S. Takenouchi, (editors), "Mining Geology Special", No. 8, Society of Mining Geologists of Japan, pp. 223-242, 1980. 
[26] W. Tantiwanit, "Overview of consequences of the tsunami in Thailand and roles and activities of the Department of Mineral Resources after the 26 December 2004 Tsunami," in Seminar of Ministry of Natural Resources and Environment, Thailand, 2005.

[27] Department of Mineral Resources. (2000) Information of Thailand Geology (in Thai). Ministry of Natural Resources and Environment, Thailand, ISBN 974-7733-05-6, 2000. Available: http://www.dmr.go.th

[28] International Atomic Energy Agency, "Guidelines For Radioelement Mapping Using Gamma Ray Spectrometry Data,” TECDOC-1363, July, 2003.

[29] A. McKay and Y. Miezitis, Australia's Uranium Resources, Geology And Development Of Deposits, Geosciences Australia, ISBN 064246716 1, 2001.

[30] Cross land Uranium mines Ltd. (2006) Charley Creek Project, Northern Territory. Available: http://www.crosslanduranium.com.au/Projects/Uranium/CharleyCreek/tabid/2278/Default.aspx

[31] S. Minato, "Uranium, thorium and potassium concentrations in Japanese soils," Radioisotopes, vol. 54, pp. 543-548, 2005.

[32] G. F. Knoll, Radiation Detection and Measurements, $2^{\text {nd }}$ ed, New York: John Wiley \& Sons, 1989.

[33] A. Vértes, S. Nagy, Z. Klencsár, R. G. Lovas, and F. Rösch, "Natural radioactive decay chains," in Elements and Isotopes: Formation, Transformation, Distribution, 1st ed. KAP, 2003, ch. 2, sec. 3, pp. 49-71.

[34] International Atomic Energy Agency (IAEA). (2011). Reference products for environment and Trade. Available: http://nucleus.iaea.org/rpst/ReferenceProducts/ReferenceMaterials/ Radionuclides/index.htm

[35] International Atomic Energy Agency, "Measurement of radionuclides in Food and the Environment," Technical Report Series No. 295, Vienna: IAEA, 1989.

[36] D. Malain, P. H. Regan, D. A. Bradley, M. Matthews, T. Santawamaitre, and H. A. Al-Sulaiti, "Measurements of NORM in beach sand samples along the Andaman Coast of Thailand after the 2004 Tsunami," Nuclear Instruments and Methods in Physics Research A, vol. 619, pp. 441-445, 2010.

[37] R. Boonkrongcheep, S. Benjakul, and P. Kessaratikoon, "Specific activities and radioactive contour maps of natural $\left({ }^{40} \mathrm{~K},{ }^{226} \mathrm{Ra}\right.$ and $\left.{ }^{232} \mathrm{Th}\right)$ and anthropogenic radionuclides $\left({ }^{137} \mathrm{Cs}\right)$ in soil samples in Phuket Province, Thailand" in the 36th Congress on Science and Technology of Thailand, Bangkok, Thailand, Oct. 26-28, 2010.

[38] K. Saito and P. Jacob, "Gamma ray fields in the air due to sources in the ground," Radiat. Protect. Dosim, vol. 58, pp. 29-45.1995.

[39] N. Mohsen, I. Bahari, P. Abdullah, and A. Jaafar, "Gamma hazards and risk associated with norm in sediment from amang processing recycling ponds," The Malaysian Journal of Analytical Sciences, vol. 11, no. 1, pp. 314-323, 2007. 